\title{
Reduced incretin effect in Type 2 (non-insulin-dependent) diabetes
}

\author{
M. Nauck, F.Stöckmann, R. Ebert and W. Creutzfeldt \\ Department of Medicine, Division of Gastroenterology and Metabolism, Göttingen, FRG
}

\begin{abstract}
Summary. Integrated incremental immunoreactive insulin and connecting peptide responses to an oral glucose load of $50 \mathrm{~g}$ and an "isoglycaemic" intravenous glucose infusion, respectively, were measured in 14 Type 2 (non-insulin-dependent) diabetic patients and 8 age- and weight-matched metabolically healthy control subjects. Differences between responses to oral and intravenous glucose administration are attributed to factors other than glucose itself (incretin effect). Despite higher glucose increases, immunoreactive insulin and connecting peptide responses after oral glucose were delayed in diabetic patients. Integrated responses were not significantly different between both groups. However, during "isoglycaemic" intravenous infusion, insulin and connecting peptide responses were greater in diabetic patients than in control subjects as a consequence of the higher glycaemic stimulus. The contribution of incretin factors to total insulin responses was $72.8 \pm$ $6.9 \%(100 \%=$ response to oral load $)$ in control subjects and $36.0 \pm 8.8 \%$ in diabetic patients ( $p \leqq 0.05$ ). The contribution to
\end{abstract}

connecting peptide responses was $58.4 \pm 7.6 \%$ in control subjects and 7.6 $\pm 14.5 \%(p \leqq 0.05)$ in diabetic patients. Ratios of integrated insulin to connecting peptide responses suggest a reduced (hepatic) insulin extraction in control subjects after oral as compared to intravenous glucose. This was not the case in diabetic patients. Immunoreactive gastric inhibitory polypeptide responses were not different between control subjects and diabetic patients. A reduced or lost incretin effect in the face of normal gastric inhibitory polypeptide response in Type 2 diabetic patients may be explained by decreased sensitivity of the B cells towards the insulinotropic effect of gastric inhibitory polypeptide or to hyposecretion or reduced effectiveness of as yet unidentified humoral or nervous gut factors with incretin activity.

Key words: Insulin secretion, Type 2 (non-insulin-dependent) diabetes, incretin effect, gastrointestinal hormones, gastric inhibitory polypeptide.
Insulin secretion after an oral glucose load is due to stimulation of the pancreatic $B$ cell by elevation of the plasma glucose level and, in addition, by incretin factors (gastrointestinal hormones and possibly nerves) which potentiate the secretory response to hyperglycaemia alone [1, 2].

In Type 2 (non-insulin-dependent) diabetic patients, insulin secretion to oral [3] and intravenous [4] glucose is inadequately slow, and the insulin levels achieved are not sufficient to maintain euglycaemia. A reduced responsiveness of the B cell to direct glycaemic stimulation has been well established [5]. However, less is known about the activity of the entero-insular axis in Type 2 diabetic patients, which in healthy control subjects contributes up to $62.9 \%$ of the total connecting (C-) peptide response after oral glucose [6]. Due to possible changes in (hepatic) insulin extraction induced by glucose ingestion but not intravenous glucose infusion [7-9], insulin secretion cannot be safely estimated from peripheral venous insulin responses alone. C-peptide, on the other hand, can be used to determine B cell secretory responses. Thus the study of Perley and Kipnis [10] from 1967 does not - in the absence of C-peptide measurements - allow final conclusions about the incretin effect in Type 2 diabetic patients.

Of the known hormones with incretin activity, gastric inhibitory polypeptide (GIP) release after oral glucose and test meals has been studied and found to be increased [11-15] or unchanged [16, 17] in Type 2 diabetic patients as compared to control subjects. Preliminary studies have shown a decreased incretin effect in Type 2 diabetic patients but no correlation to the GIP response to oral glucose [18].

In the present study, the incretin effect was quantified in Type 2 diabetic patients and compared to metabolically healthy control subjects. An attempt was made to correlate the contribution of incretin factors to plasma GIP responses after oral glucose. 
Table 1. Clinical characteristics of 14 Type 2 diabetic patients (D) and 8 metabolically healthy control (C) subjects

\begin{tabular}{|c|c|c|c|c|c|c|c|c|c|}
\hline \multirow{4}{*}{$\begin{array}{l}\text { Patient } \\
\text { number }\end{array}$} & \multirow{4}{*}{$\begin{array}{l}\text { Sex } \\
M / F\end{array}$} & \multirow{4}{*}{$\begin{array}{l}\text { Age } \\
\text { y }\end{array}$} & \multirow{4}{*}{$\begin{array}{l}\text { Body } \\
\text { mass } \\
\text { index } \\
\mathrm{kg} / \mathrm{m}^{2}\end{array}$} & \multirow{4}{*}{$\begin{array}{l}\text { Known } \\
\text { duration } \\
\text { of } \\
\text { diabetes } \\
\text { y }\end{array}$} & \multicolumn{4}{|c|}{ Glycaemic control with treatment before the study } & \multirow{2}{*}{$\begin{array}{l}\text { Diagnostic oral } \\
\text { glucose tolerance test } \\
(50 \mathrm{~g} / 400 \mathrm{ml})\end{array}$} \\
\hline & & & & & \multirow{2}{*}{$\begin{array}{l}\text { Fasting } \\
\text { plasma } \\
\text { glucose }\end{array}$} & \multirow{3}{*}{$\begin{array}{l}\text { Postprandial } \\
\text { plasma } \\
\text { glucose }^{\mathrm{a}} \\
\mathrm{mmol} / \mathrm{l}\end{array}$} & \multirow{3}{*}{$\begin{array}{l}\text { Glucos- } \\
\text { uria } \\
+1-\end{array}$} & \multirow{3}{*}{$\begin{array}{l}\text { Treat- } \\
\text { ment } \\
\mathrm{D}, \mathrm{S}^{\mathrm{b}}\end{array}$} & \\
\hline & & & & & & & & & $\begin{array}{l}\text { Plasma glucose } \\
\text { at } 120 \mathrm{~min}\end{array}$ \\
\hline & & & & & $\mathrm{mmol} / 1$ & & & & $\mathrm{mmol} / 1$ \\
\hline D 1 & $\mathrm{~F}$ & 62 & 23.8 & 6 & 4.6 & 10.2 & - & $\mathrm{D}, \mathrm{S}$ & 20.5 \\
\hline D 2 & $\mathrm{M}$ & 52 & 30.3 & 11 & 10.3 & 12.7 & - & $\mathrm{D}, \mathrm{S}$ & 14.4 \\
\hline D 3 & $\mathrm{M}$ & 71 & 21.8 & 25 & 10.1 & 9.3 & + & $\mathrm{D}, \mathrm{S}$ & 12.3 \\
\hline D 4 & $\mathrm{~F}$ & 71 & 24.2 & $\mathrm{ND}^{\mathrm{c}}$ & 6.8 & 10.5 & - & $\mathrm{D}$ & 14.4 \\
\hline D 5 & $\mathrm{~F}$ & 71 & 23.2 & 1 & 10.9 & 13.4 & + & $\mathrm{D}, \mathrm{S}$ & 16.2 \\
\hline D 6 & M & 63 & 27.3 & 13 & 9.4 & 12.7 & + & $\mathrm{D}$ & 14.6 \\
\hline D 7 & $\mathrm{~F}$ & 54 & 24.0 & 6 & 11.0 & 12.6 & - & $\mathrm{D}$ & 18.4 \\
\hline D 8 & $\mathrm{~F}$ & 72 & 25.0 & 6 & 5.8 & 6.7 & - & $\mathrm{D}$ & 12.1 \\
\hline D 9 & $\mathrm{M}$ & 39 & 27.0 & 1 & 7.5 & 7.4 & - & D & 14.1 \\
\hline D 10 & $\mathrm{~F}$ & 46 & 21.4 & 13 & 12.4 & 14.1 & + & D & 21.5 \\
\hline D 11 & $\mathrm{M}$ & 51 & 27.9 & 1 & 5.8 & 7.8 & - & $\mathrm{D}$ & 10.5 \\
\hline D 12 & $\mathrm{M}$ & 64 & 25.8 & 1 & 6.1 & 7.2 & - & D & 10.7 \\
\hline D 13 & $\mathrm{M}$ & 67 & 30.5 & 4 & 8.1 & 11.7 & - & D & 15.1 \\
\hline D 14 & $\mathrm{~F}$ & 70 & 20.8 & 8 & 8.0 & 8.3 & - & $\mathrm{D}, \mathrm{S}$ & 16.6 \\
\hline $\mathrm{x}$ & & 61 & 25.2 & 7 & 8.3 & 10.3 & & & 15.1 \\
\hline $\mathrm{SD}$ & & 11 & 3.1 & 7 & 2.4 & 2.6 & & & 3.3 \\
\hline SEM & & 3 & 0.8 & 2 & 0.6 & 0.7 & & & 0.9 \\
\hline$\overline{\mathrm{C} 1}$ & $\mathrm{M}$ & 77 & 23.4 & - & 5.4 & 7.4 & - & - & 5.2 \\
\hline C 2 & $\mathrm{M}$ & 52 & 23.1 & - & 4.8 & 7.4 & - & - & 4.9 \\
\hline C 3 & $\mathrm{~F}$ & 45 & 21.4 & - & 4.8 & 5.2 & - & - & 4.2 \\
\hline $\mathrm{C} 4$ & $F$ & 68 & 20.7 & - & 4.6 & 7.7 & - & - & 5.7 \\
\hline C 5 & M & 52 & 28.7 & - & 5.3 & 7.5 & - & - & 5.8 \\
\hline C 6 & $\mathrm{~F}$ & 54 & 22.5 & - & 4.6 & 5.2 & - & - & 2.8 \\
\hline C 7 & M & 46 & 24.6 & - & 4.3 & 6.1 & - & - & 3.0 \\
\hline C 8 & $M$ & 57 & 24.5 & - & 4.9 & 6.4 & $+^{d}$ & - & 4.9 \\
\hline $\mathrm{x}$ & & 56 & 23.6 & & 4.8 & 6.6 & & & 4.6 \\
\hline SD & & 11 & 2.5 & & 0.4 & 1.1 & & & 1.2 \\
\hline SEM & & 4 & 0.9 & & 0.1 & 0.4 & & & 0.3 \\
\hline
\end{tabular}

a 08.30 hours $(1 \mathrm{~h}$ after breakfast $){ }^{\mathrm{b}} \mathrm{D}=$ diet, $\mathrm{S}=$ sulfonyl urea compound; ${ }^{\mathrm{c}} \mathrm{ND}=$ newly diagnosed; ${ }^{\mathrm{d}}$ nondiabetic glucosuria

\section{Subjects and methods}

\section{Subjects}

Fourteen Type 2 diabetic patients (D) and eight metabolically healthy control subjects (C) were studied. All consumed their normal weightmaintaining diet and performed unrestricted physical activities. The diagnosis was based on the results of an oral glucose tolerance test using the WHO criteria [19] as modified for a $50 \mathrm{~g}$ oral glucose load [20]. The upper limit of normal for the 120 -min venous plasma glucose value was $6.8 \mathrm{mmol} / \mathrm{l}(123 \mathrm{mg} / \mathrm{dl})$; values of higher than $9.8 \mathrm{mmol} / \mathrm{l}$ $(176 \mathrm{mg} / \mathrm{dl})$ were considered a diagnosis of diabetes. Subject characteristics are shown in Table 1. Lean and moderately obese subjects were studied. Nonproliferative diabetic retinopathy was present in one patient (D3). Mild diabetic polyneuropathy was present in two patients (D 1, D 10). Macroangiopathy/atherosclerosis was present in $50 \%$ ( 7 out of 14) of the diabetic patients as well as in control subjects (4 out of 8 ). There was no significant nephropathy as shown by the absence of proteinuria and normal plasma creatinine concentrations. Transaminase levels were normal except in one diabetic patient (D 10) in whom steatosis was diagnosed by biopsy. Oral hypoglycaemic agents (taken by 5 patients) were discontinued at least 3 days before the study and no other medication known to interfere with insulin secretion or glucose tolerance [21] was taken except for diuretics. Care was taken to exclude potassium depletion as a possible reason for an impaired glucose tolerance [22]. Informed consent was obtained from all participants after the nature and possible risks of the study had been explained. The study protocol was approved by the local committee for ethics in human research.

\section{Methods}

All tests were performed in the morning after an overnight ( $\geqq 10 \mathrm{~h}$ ) fast. Indwelling cannulas were placed into antecubital veins. Glucose infusions and blood sampling were performed on contralateral arms.

1. Oral glucose loads: glucose was ingested as a standard mixture of glucose and low molecular weight oligomers (OGTT Boehringer, Mannheim, FRG). The standard glucose load was $50 \mathrm{~g}$ dissolved in $400 \mathrm{ml}$. Blood was sampled into heparinized tubes at $-10\left(0_{1}\right),-5$ $\left(0_{2}\right), 15,30,45,60,75,90,105,120,150$ and $180 \mathrm{~min}$ and stored on ice. $100 \mu \mathrm{l}$ of blood were stored in NaF for subsequent glucose determinations. Blood cells were sedimented by centrifugation and plasma samples were stored frozen at $-20^{\circ} \mathrm{C}$ until hormone assays were performed.

2. "Isoglycaemic" intravenous glucose infusions: intravenous infusions of glucose (as a sterile $20 \%$ solution in water) were designed to mimic glucose concentration profiles after glucose ingestion. Accuracy was assured by repeatedly estimating plasma glucose using a reflometric method (Reflocheck, Boehringer, Mannheim, FRG). A delay of only $2.5 \mathrm{~min}$ between blood sampling and knowledge of the 

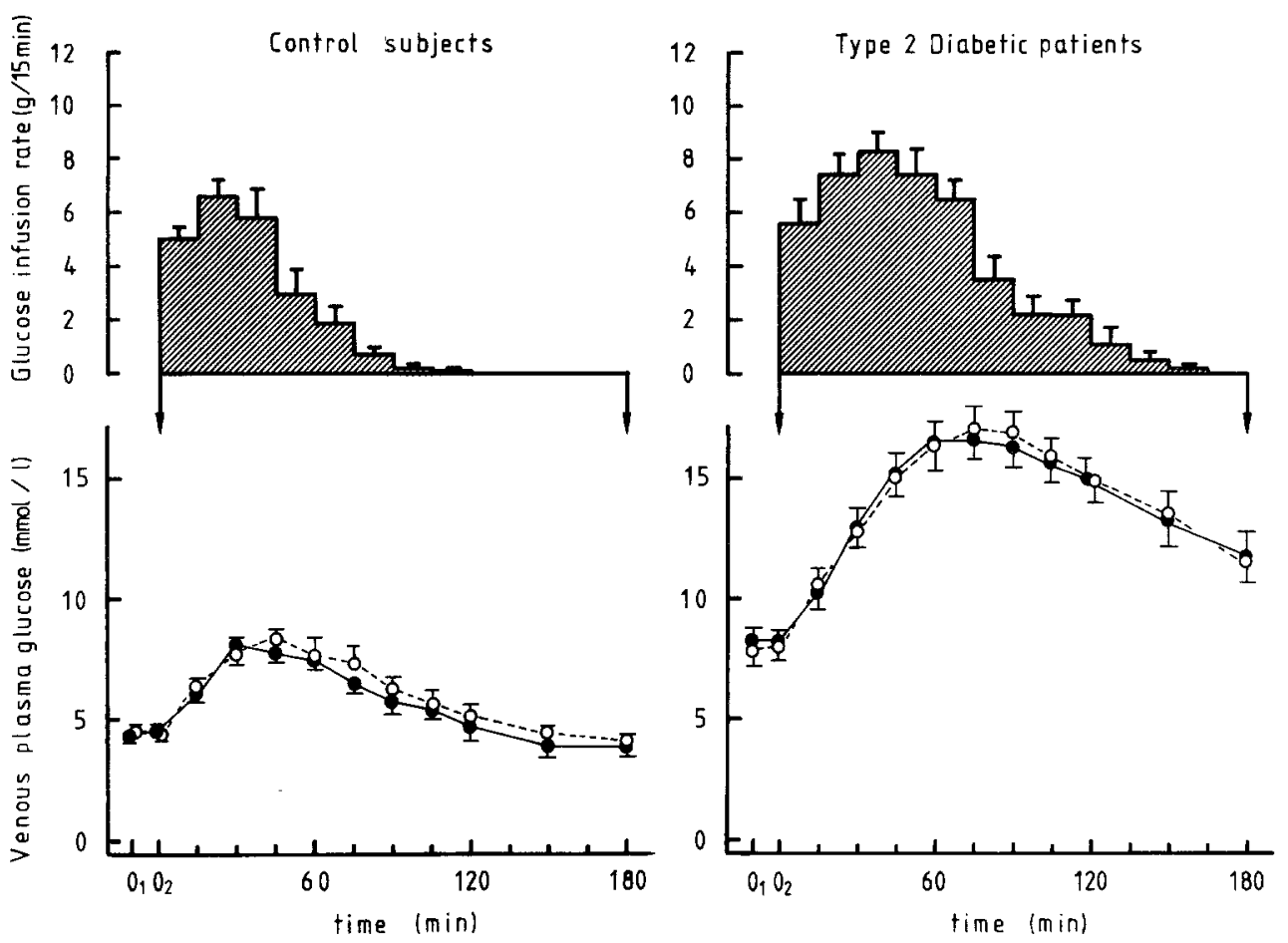

Fig. 1. Venous plasma glucose after an oral glucose load $(50 \mathrm{~g} / 400 \mathrm{ml}$; - ) and during "isoglycaemic" intravenous glucose infusion $(O----O)$ in metabolically healthy control subjects and Type 2 diabetic patients (lower panel). The infusion protocol is shown in the upper panel
Table 2. Glucose infusion during isoglycaemic intravenous glucose infusion (over $180 \mathrm{~min}$ ) and integrated incremental responses of glucose and immunoreactive gastric inhibitory polypeptide (IR-GIP) to oral glucose $(50 \mathrm{~g} / 400 \mathrm{ml})$ and isoglycaemic intravenous glucose in metabolically healthy control subjects and Type 2 diabetic patients

\begin{tabular}{lcc}
\hline & $\begin{array}{l}\text { Control subjects } \\
(n=8)\end{array}$ & $\begin{array}{l}\text { Type 2 diabetic } \\
\text { patients }(n=14)\end{array}$ \\
\hline Glucose infusion $(\mathrm{g})$ & $23.6 \pm 2.9$ & $44.6 \pm 2.2^{\mathrm{b}}$ \\
Glucose $\left(\mathrm{mmol} \cdot \mathrm{I}^{-1} \cdot \mathrm{min}\right)$ & $220 \pm 28$ & $1062 \pm 73^{\mathrm{b}}$ \\
$\quad$ Oral & $287 \pm 44$ & $1092 \pm 73^{\mathrm{b}}$ \\
$\quad$ Intravenous & & \\
IR-GIP $\left(\mathrm{ng} \cdot \mathrm{ml}^{-1} \cdot \mathrm{min}\right)$ & $162.4 \pm 20.5$ & $139.9 \pm 18.9$ \\
$\quad$ Oral & $-29.6 \pm 11.9^{\mathrm{a}}$ & $-24.4 \pm 15.1^{\mathrm{a}}$ \\
$\quad$ Intravenous &
\end{tabular}

Significant differences (Student's t-test for unpaired data, $p \leqq 0.05$ ) to ${ }^{a}$ the respective value after oral glucose, and ${ }^{b}$ the respective value in control subjects

glucose concentration allowed frequent adjustments of the infusion rate according to deviations from the profile that was to be copied. Blood samples were drawn and treated as described for oral glucose loads.

\section{Laboratory analyses}

Glucose was assayed immediately using a Beckman Glucose analyser II (glucose oxidase method). Insulin immunoreactivity (IR-insulin) was determined according to Melani et al. [23] using human insulin as a standard. Interassay coefficients of variation for basal $(6.3 \pm$ $0.5 \mathrm{mU} / \mathrm{l})$ and glucose stimulated $(45.0 \pm 1.8 \mathrm{mU} / 1)$ values were 23.3 and $13.4 \%(n=10)$. Immunoreactive (IR-) C-peptide was measured using a commercial radioimmunoassay kit (Novo Research, Bagsvaerd, Denmark) as described by Heding [24]. Interassay coefficients of variation for basal $(0.32 \pm 0.02 \mathrm{nmol} / \mathrm{l})$ and glucose stimulated $(1.74 \pm 0.06 \mathrm{nmol} / 1)$ values were 17.7 and $11.1 \%$. Gastric inhibitory polypeptide (IR-GIP) was measured by the method of Kuzio et al. [25] using antibody Goe 5/76/9 and natural porcine GIP (purchased from J.C. Brown) as a standard. Modifications and data on precision of this assay have been described elsewhere [26].

\section{Statistical analysis}

All values are presented as mean \pm SEM for the number of determinations shown unless otherwise stated. Values under the detection limits for IR-insulin ( $3 \mathrm{mU} / 1$ or $0.022 \mathrm{nmol} / \mathrm{l})$ and GIP $(31.5 \mathrm{pg} / \mathrm{ml})$ were calculated as $2 \mathrm{mU} / 1$ or $0.014 \mathrm{nmol} / 1$ and $20 \mathrm{pg} / \mathrm{ml}$ respectively.

Total responses were estimated as integrated incremental concentrations over a period of $180 \mathrm{~min}$ according to the trapezoidal rule.

Significances of difference were estimated by Student's t-test for unpaired data; $p$-values of 0.05 or less were considered significant.

\section{Results}

Fasting plasma glucose values and responses to glucose $(50 \mathrm{~g})$ ingestion display the characteristic differences between normal and diabetic glucose tolerance in control subjects and Type 2 diabetic patients (Fig. 1). Glucose profiles during the intravenous glucose infusion experiments closely mimicked those after glucose ingestion. They could therefore be termed "isoglycaemic". The total amount of intravenous glucose necessary to achieve "isoglycaemia" was considerably greater in diabetic patients $(44.6 \pm 2.2 \mathrm{~g}$ vs. $23.6 \pm 2.9 \mathrm{~g}$ in control subjects, $p=0.001$ ). In diabetic subjects, it came remarkably close to the oral load of $50 \mathrm{~g}$ (Table 2).

IR-insulin and IR-C-peptide concentrations in the fasting state were higher in diabetic patients than in control subjects (Fig. $2, p \leqq 0.01$ ). The B cell secretory response to glucose ingestion, as judged from increases in plasma IR-insulin and IR-C-peptide, was slower in diabetic patients. Peak IR-insulin and IR-C-peptide 

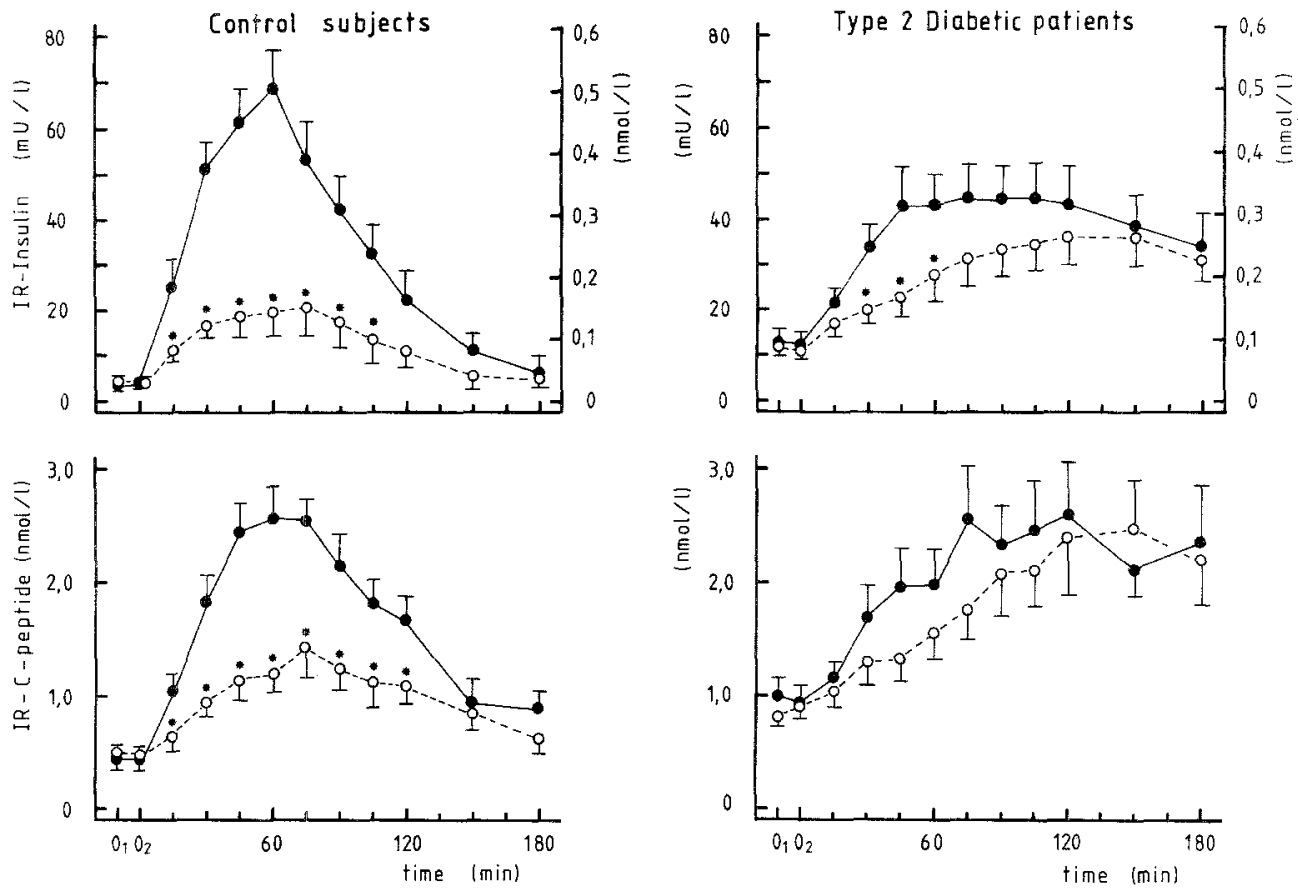

Fig. 2. Venous IR-insulin (upper panels) and IR-C-peptide (lower panels) after an oral glucose load $(50 \mathrm{~g} / 400 \mathrm{ml} ;-)$ and during "isoglycaemic" intravenous glucose infusion (O--. 0 ) in metabolically healthy control subjects and Type 2 diabetic patients. For comparison: $1 \mathrm{mU} / 1$ Insulin $=0.0073 \mathrm{nmol} / 1$. Asterisks denote significant difference $(p \leqq 0.05)$ to the respective value after the oral load

Table ${ }^{1}$. Integrated incremental B cell secretory (IR-insulin and IRC-peptide) responses (over $180 \mathrm{~min}$ ) to oral glucose $(50 \mathrm{~g} / 400 \mathrm{ml})$ and isoglycaemic intravenous glucose and quantified incretin effects (in \% of the B-cell secretory response after the ingestion of $50 \mathrm{~g}$ of oral glucose) in healthy control subjects and Type 2 diabetic patients

\begin{tabular}{lcc}
\hline & $\begin{array}{l}\text { Control subjects } \\
(n=8)\end{array}$ & $\begin{array}{l}\text { Type 2 diabetic } \\
\text { patients } \\
(n=14)\end{array}$ \\
\hline $\begin{array}{l}\text { Integrated B cell secretory } \\
\text { responses } \\
(n \text { mol })^{-l} \cdot \text { min) }\end{array}$ & \\
IR-insulin & \\
$\quad$ Oral & & \\
$\quad$ Intravenous & $38.9 \pm 4.2$ & $34.7 \pm 6.0$ \\
IR-C-peptide & $11.3 \pm 3.3^{\mathrm{a}}$ & $23.5 \pm 5.0^{\mathrm{a}, \mathrm{b}}$ \\
$\quad$ Oral & & \\
$\quad$ Intravenous & $222.4 \pm 22.3$ & $202.2 \pm 34.6$ \\
\hline $\begin{array}{l}\text { Incretin effects (\%) } \\
\text { IR-insulin }\end{array}$ & $92.2 \pm 17.0^{\mathrm{a}}$ & $181.1 \pm 37.8^{\mathrm{b}}$ \\
IR-C-peptide & $72.8 \pm 6.9$ & $30.0 \pm 8.8^{\mathrm{b}}$ \\
\hline
\end{tabular}

Significant differences (Student's t-test for unpaired data, $p \leqq 0.05$ ) to ${ }^{a}$ the respective value after oral glucose, and ${ }^{b}$ the respective value in control subjects

1 This table is a detailed account of Figure 6 displayed in a review article published on the occasion of the 20th anniversary of this journal [Creutzfeldt W and Ebert R: New developments in the incretin concept (1985) Diabetologia 28: 565-573]

values were observed earlier in control subjects. During the course of "isoglycaemic" intravenous glucose infusion experiments, greater $\mathrm{B}$ cell secretory responses were observed in diabetic patients (Fig. 2, Table 3). Under this condition, however, the glycaemic stimulus was higher in diabetic patients than in control subjects due to their glucose profiles (Fig.1, Table 2). Whereas differences in B cell secretory responses to oral as compared to "isoglycaemic" intravenous glucose administration were obvious in control subjects, they appeared to be reduced in Type 2 diabetic patients. No significant differences in IR-C-peptide concentrations were noted between both ways of glucose administration in diabetic patients (Fig. 2). Likewise, there was no significant difference in integrated incremental IR-C-peptide responses (Table 3 ). The quantity of B cell secretory response evoked by factors other than glucose itself (incretin effect) is represented by the difference in integrated incremental responses (over basal) of IR-insulin $\left(\int\right.$ IR-I) or IR-C-peptide ( $\int$ IR-CP) between oral glucose ingestion and the respective "isoglycaemic" glucose infusion experiment. This difference in integrated secretory responses ( $\int S R$ ) can be expressed as the percentage of the response to oral glucose by the formula:

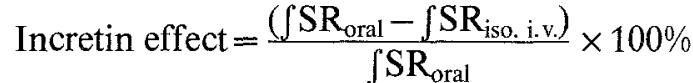

The participation of incretin factors in the B-cell secretory response to glucose ingestion can thus be expressed in quantitative terms. According to this formula, apparent incretin effects were lower in Type 2 diabetic patients than in control subjects (Table 3), no matter whether calculations were based on insulin $(p \leqq 0.002)$ or on C-peptide ( $p \leqq 0.001)$ integrated incremental responses. In line with previous studies, apparent incretin effects (in \% of the B cell secretory response after glucose ingestion) were lower when they were derived from Cpeptide as compared to insulin responses $[6,7]$. This was significant in diabetic patients $(\mathrm{p} \leqq 0.005)$ but not in control subjects $(p=0.088)$. In Type 2 diabetic patients, the incretin effect (calculated from IR-CP responses) was not significantly different from zero $(p=0.306)$.

The ratio of $\int I R-I$ to $\int I R-C P$ responses was greater after oral glucose than during intravenous glucose infu- 
Control Type 2 diabetic subjects patients

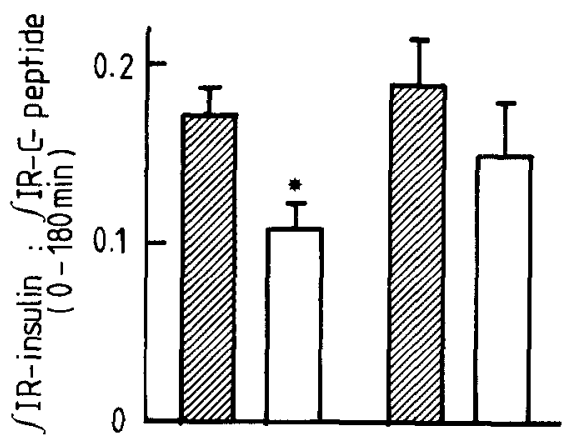

Fig.3. The ratio of integrated incremental reponses of IR-insulin ( $\int$ IR-Insulin) and IR-C-peptide ( $\int$ IR-C-Peptide) after an oral glucose load $(50 \mathrm{~g} / 400 \mathrm{ml}$; hatched bars) and during "isoglycaemic" intravenous glucose infusion (open bars) is shown for metabolically healthy control subjects and for Type 2 diabetic patients. The asterisk denotes a significant difference to the respective value after the oral glucose load

sion in control subjects (Fig. 3, $p=0.04$ ), but this difference was not significant in diabetic patients $(p=0.116)$.

Mean basal GIP values and GIP responses to oral glucose were similar in control subjects and in Type 2 diabetic patients (Fig.4, Table 2). No significant difference was observed throughout the period of observation. However, the range of GIP responses was much larger in diabetic patients.

When apparent incretin effects based on insulin responses (Fig. 5, upper panel) were correlated to GIP responses after oral glucose, no significant positive correlation was observed in Type 2 diabetic patients $(r=0.174)$ or in control subjects $(r=-0.653)$. Similarly, incretin effects calculated from C-peptide (Fig. 5, lower panel) responses did not correlate with GIP responses $(r=-0.378)$ in control subjects. The positive correlation in Type 2 diabetic patients $(r=0.503, p \leqq 0.05)$ relied on a single patient with an apparent incretin effect of $-142.7 \%$ (Fig. 5 , bottom) and was reduced to insignificance $(r=0.288)$ when this patient was eliminated from the calculation.

\section{Discussion}

In Type 2 diabetic patients the incretin effect of $50 \mathrm{~g}$ of glucose was quantified and found to be generally reduced or - in some patients - even absent.

Insulin secretion can be more reliably estimated from peripheral C-peptide rather than insulin responses [27]. This is due to a non-constant insulin extraction from plasma [7-9]. Changes are induced, for example, by portal hyperglycaemia $[28,29]$ or hyperinsulinaemia
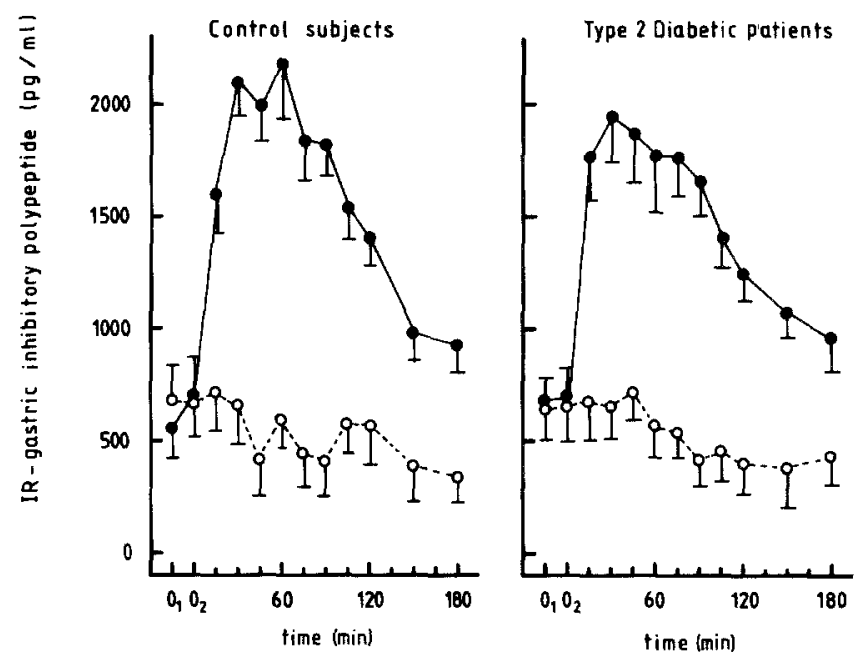

Fig.4. Venous IR-gastric inhibitory polypeptide after an oral glucose load $(50 \mathrm{~g} / 400 \mathrm{ml} ;-0)$ and during "isoglycaemic" intravenous glucose infusion $(\mathrm{O}---\mathrm{O})$ in metabolically healthy control subjects and Type 2 diabetic patients
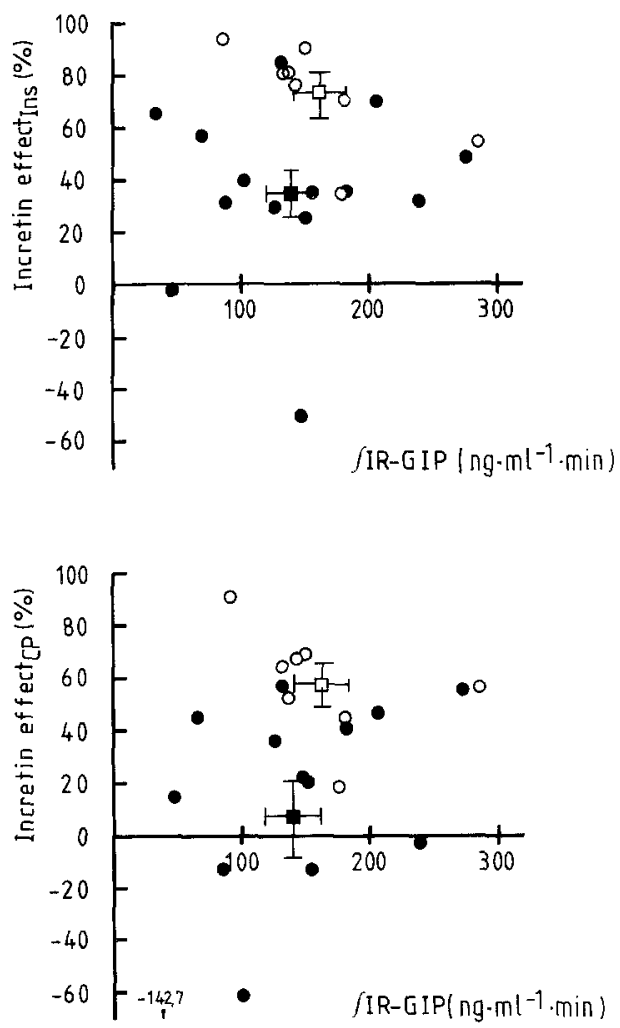

Fig.5. Apparent incretin effects calculated from peripheral venous IR-insulin (incretin effect ${ }_{\text {lns }}$, upper panel) and IR-C-peptide (incretin effect $_{C P}$, lower panel) are plotted against IR-GIP-responses for individual Type 2 diabetic patients ( ) and metabolically healthy control subjects $(O)$. Square symbols indicate mean $\pm S E M$ for Type 2 diabetic patients (closed symbols) and control subjects (open symbols). Note an individual patient with an apparent incretin effect (based on C-peptide responses) of $-142.7 \%$ 
[30] and, possibly, by gastrointestinal factors released after glucose ingestion [6]. C-peptide elimination from plasma, in contrast, seems not to be affected by the level of glycaemia [31], C-peptide concentration (constant metabolic clearance rate over a wide range of physiological C-peptide concentrations [32]), and factors released by glucose ingestion [33]. This explains why the numerical values for the apparent incretin effect depend on whether they are calculated from insulin- or Cpeptide responses, although both polypeptides are secreted into the portal circulation in equimolar amounts [34]. No difference of metabolic clearance rates was measured after the infusion of human $\mathrm{C}$-peptide into healthy and diabetic subjects [35].

The insignificantly reduced "alimentary stimulus" in mild diabetes described by Perley and Kipnis [10] was deduced solely from peripheral venous insulin responses. The numerical incretin effect (according to our method of calculation) was $61 \%$ in lean, and $56 \%$ in grossly obese mild diabetic subjects. As can be deduced from the plasma glucose profiles, most of the individuals would have to be classified as "impaired glucose tolerance" according to current criteria [19, 21]. Furthermore, the oral glucose load was $100 \mathrm{~g}$; it cannot be excluded from the present data that oral glucose loads larger than $50 \mathrm{~g}$ would elicit a greater incretin effect in Type 2 diabetic patients. In healthy young subjects, a clear dose-dependency of incretin effects after oral glucose has been observed [6].

The markedly reduced incretin effect found in our group with a more severe degree of Type 2 diabetes may simply be an expression of their impaired capacity to secrete insulin at an adequate rate $[3,4]$. The glycaemic stimulus with plasma glucose values of $\sim 17 \mathrm{mmol} / 1$ $(300 \mathrm{mg} / \mathrm{dl})$ may already have led to maximal B cell stimulation. No further increase in the secretion rate would then be possible if additional stimuli (like incretin factors) were superimposed. Arguing against this explanation, intravenous isoproterenol [36] or glucagon [37] enhanced, rather than diminished, additional B cell secretory responses in Type 2 diabetic patients when plasma glucose levels had been elevated by glucose infusion up to the range employed in our study.

The systematic discrepancy of apparent incretin effects based on insulin- versus C-peptide responses noted previously [6-9] is also obvious from the present study. This is demonstrable as a different ratio of insulin and C-peptide integrated incremental responses when oral glucose loads and isoglycaemic intravenous glucose infusion experiments are compared (Fig.3). Although this value does not represent a direct measure of (hepatic) insulin extraction [33], it does indicate changes in the elimination from plasma of either insulin or Cpeptide and can most probably be used as a rough estimate of the amount of insulin present in the circulation per unit of insulin (C-peptide) secreted [8].

In Type 2 diabetic patients, the characteristic difference between responses to glucose ingestion and intra- venous glucose infusion seen in healthy control subjects (Fig.3) is lost; during intravenous glucose infusion, leading to clearly hyperglycaemic values (Fig.1), the finsulin: $\int \mathrm{C}$-peptide ratio is already elevated as compared to control subjects $(p=0.102)$. This may be attributed to hyperglycaemia [28] and the hepatic insulin resistance characteristic of Type 2 diabetic patients [38], since hepatic insulin extraction appears to correlate with hepatic effects of insulin under certain conditions [39]. This conclusion must, however, remain speculative because of reservations regarding the "insulin to C-peptide ratio method" for estimating changes in (hepatic) insulin extraction [33].

GIP secretion in our group of Type 2 diabetic patients was not different from normal (Fig. 4). Previously, hypersecretion of GIP after oral glucose had been found in some [11-14], but not all [16, 17], studies. In a large series of Type 2 diabetic patients studied, a bimodal distribution of GIP secretion after oral glucose was found, thus demonstrating hyper - as well as hyposecretion $[15,18]$. In the present study, both secretory patterns were represented (Fig. 5) without any overt correlation to the incretin effect. Obviously changes in GIP responses are not necessarily identical with changes in the activity of the entero-insular axis [18]. Two explanations for this may be discussed. A reduced effect of exogenous GIP on insulin secretion in Type 2 diabetic patients has been described [40,41], suggesting an impaired responsiveness to incretin stimulation of the $\mathrm{B}$ cell. On the other hand, additional incretin factors have been postulated because GIP antiserum does not completely eliminate incretin effects when applied intravenously [42], and duodenal extracts freed from GIP still display incretin activity [43]. Hyposecretion of such factors as a cause of a reduced incretin effect in diabetic patients cannot be ruled out until these factors are characterized. The alternative explanation that a reduced secretion of unknown incretin factors could be due to a desensitisation of the entero-insular axis as a consequence of longstanding hyperglycaemia has then to be considered.

In conclusion, a reduced incretin effect in Type 2 diabetes has been demonstrated in the presence of normal GIP secretion. This suggests a possible loss of B cell responsiveness to the actions of GIP or a loss of additional incretin factors.

Acknowledgements. The expert technical assistence of M Ungricht, $\mathrm{K}$ Jänsch, $\mathrm{K}$ Illmer and S Beck is gratefully acknowledged. This study was supported by grant Cr. 20/17 of the Deutsche Forschungsgemeinschaft.

\section{References}

1. Creutzfeldt W (1979) The incretin concept today. Diabetologia 16: 75-85

2. Unger RH, Eisentraut AM (1969) Entero-insular axis. Arch Int Med 123: 261-266

3. Seltzer HS, Allen EW, Herron AL Jr, Brennan MT (1967) Insulin secretion in response to glycemic stimulus: Relation of delayed 
initial response to carbohydrate intolerance in mild diabetes. $J$ Clin Invest 45: 323-335

4. Cerasi E, Luft R (1967) the plasma insulin response to glucose infusion in healthy subjects and in diabetes mellitus. Acta Endocrinol 55: 278-304

5. Reaven GM, Farquhar JW (1969) Steady state plasma insulin response to continuous glucose infusion in normal and diabetic subjects. Diabetes 18: 273-279

6. Nauck M, Homberger E, Siegel EG, Ebert R, Creutzfeldt W (1985) Incretin effects of increasing glucose loads in man calculated from venous insulin and C-peptide responses. Diabetes Res Clin Pract 9 (Suppl 1): S 403 (Abstract)

7. Faber OK, Madsbad S, Kehlet H, Binder C (1979) Pancreatic beta cell secretion during oral and intravenous glucose administration. Acta Med Scand (Suppl) 624: 61-64

8. Gibby OM, Hales CN (1983) Oral glucose decreases hepatic extraction of insulin. Br Med J 286: 921-923

9. Madsbad S, Kehlet H, Hilsted J, Tronnier B (1983) Discrepancy between plasma C-peptide and insulin response to oral and intravenous glucose. Diabetes 32: 436-438

10. Perley MJ, Kipnis D (1967) Plasma insulin responses to oral and intravenous glucose: Studies in normal and diabetic subjects. J Clin Invest 46: 1954-1962

11. Crockett SE, Mazzaferri EC, Cataland S (1976) Gastric Inhibitory Polypeptide (GIP) in maturity-onset diabetes mellitus. Diabetes 25:931-935

12. Ebert R, Frerichs H, Creutzfeldt W (1976) Serum Gastric Inhibitory Polypeptide (GIP) responses in patients with maturity onset diabetes and in juvenile diabetes. Diabetologia 12: 388 (Abstract)

13. Ross SA, Brown JC, Dupre J (1977) Hypersecretion of Gastric Inhibitory Polypeptide following oral glucose in diabetes mellitus. Diabetes 26: 525-529

14. Salera M, Giacomoni P, Pironi L, Cornia G, Capulli M, Marini A, Benfenati F, Miglioli M and Barbara C (1982) Gastric Inhibitory Polypeptide release after oral glucose: Relationship to glucose intolerance, diabetes mellitus and obesity. J Clin Endocrinol Metab 55: $329-336$

15. Ebert R, Creutzfeldt W (1980) Hypo- and hypersecretion of GIP in maturity-onset diabetics. Diabetologia 19: 271-272 (Abstract)

16. Bloom SR (1975) GIP in diabetes (abstract). Diabetologia 11: 334

17. May JM, Williams RH (1978) The effect of endogenous Gastric Inhibitory Polypeptide on glucose-induced insulin secretion in mild diabetes. Diabetes 27: 849-855

18. Creutzfeldt W, Ebert R, Nauck M, Stöckmann F (1983) Disturbances of the entero-insular axis. Scand J Gastroenterol 18 (Suppl 82): $111-119$

19. WHO Expert Committee on Diabetes Mellitus, Second Report, Technical Report Series 646, WHO, Geneva, 1980

20. Ito C, Mito K, Hara H (1983) Review of criteria for diagnosis of diabetes mellitus based on results of follow-up study. Diabetes 28 : 1039-1057

21. National Diabetes Data Group (1979) Classification and diagnosis of diabetes mellitus and other categories of glucose intolerance. Diabetes 28: 1039-1057

22. Helderman JH, Elahi D, Andersen DK, Raizes GS, Tobin JD, Shocken D, Andres R (1983) Prevention of the glucose intolerance of thiazide diuretics by maintenance of body potassium. Diabetes 32: $106-111$

23. Melani F, Ditschuneit H, Bartelt HM, Friedrich H, Pfeiffer EF (1965) Über die radioimmunologische Bestimmung von Insulin im Blut. Klin Wochenschr 43: 1000-1006

24. Heding LG (1975) Radioimmunological determination of human C-peptide. Diabetologia 11: 541-548

25. Kuzio M, Dryburgh JR, Malloy KM, Brown JC (1974) Radioimmunoassay for gastric inhibitory polypeptide. Gastroenterol 66 357-364

26. Ebert R, Illmer K, Creutzfeldt W (1979) Release of gastric inhibitory polypeptide (GIP) by intraduodenal acidification in rats and humans and abolishment of the incretin effect of acid by GIP-antiserum in rats. Gastroenterol 76:515-523

27. Waldhaeusl W, Bratusch-Marrain P, Gasic B, Korn A, Nowotny P (1979) Insulin production rate following glucose ingestion estimated by splanchnic C-peptide output in normal man. Diabetologia 17: 221-227

28. Honey RN, Price S (1979) The determinants of insulin extraction in the isolated perdused rat liver. Horm Metab Res 11:111-117

29. Tranberg KG (1979) Hepatic uptake of insulin in man. Am J Physiol 237: E 509-518

30. Madison LL, Kaplan N (1958) The hepatic binding of I-131 labeled insulin in human subjects during a single transhepatic circulation. J Lab Clin Med 52: 927-932

31. Kuzuya T, Matsuda A (1976) Disappearance rate of endogenous human C-peptide from blood. Diabetologia 12: 519-521

32. Polonsky K, Jaspan J, Pugh W, Cohen D, Schneider T, Schwartz T, Moossa AR, Tager H, Rubenstein AH (1983) Metabolism of Cpeptide in the dog. In vivo demonstration of the absence of hepatic extraction. J Clin Invest 72: 1114-1123

33. Polonsky K, Rubenstein AH (1984) C-peptide as a measure of the secretion and hepatic extraction of insulin. Pitfalls and limitations. Diabetes 33: 486-493

34. Rubenstein AH, Clark JL, Melani F, Steiner DF (1969) Secretion of proinsulin C-peptide by pancreatic $\beta$-cells and its circulation in blood. Nature 224: 697-699

35. Faber OK, Hagen C, Binder C, Markussen J, Naithani VK, Blix PM, Kuzuya H, Horwitz DL, Rubenstein AH, Rossing N (1978) Kinetics of human connecting peptide in normal and diabetic subjects. J Clin Invest 62: 197-203

36. Halter JB, Graf RJ, Porte D Jr. (1979) Potentiation of insulin secretory responses by plasma glucose levels in man: Evidence that hyperglycaemia in diabetes compensates for impaired glucose potentiation. J Clin Endocrinol Metab 48: 946-954

37. Garvey WT, Olefsky JM, Griffin J, Hamman RF, Kolterman OG (1985) The effect of insulin treatment on insulin secretion and insulin action in type 2 diabetes mellitus. Diabetes 34: 222-234

38. Kimmerling G, Javorski WC, Olefsky JM, Reaven GM (1976) Locating the site(s) of insulin resistance in patients with nonketotic diabetes mellitus. Diabetes 25: 673-678

39. Jaspan J, Polonsky K (1982) Glucose ingestion in dogs alters the hepatic extraction of insulin: In vivo evidence for a relation between biologic action and extraction of insulin. J Clin Invest 69: 516-525

40. Ross SA, Brown JC, Dupre J (1974) Effects of Gastric Inhibitory Polypeptide on endocrine pancreas in normal and diabetic subjects. Diabetologia 10:384 (Abstract)

41. Kranıp T, Moody AJ, Saurbrey N, Kühl C, Madsbad S (1984) Effect of porcine gastric inhibitory polypeptide on $\beta$-cell-function in type 1 (insulin dependent) and type 2 (non-insulin-dependent) diabetes. Diabetologia 27:299 (Abstract)

42. Ebert R, Creutzfeldt W (1982) Influence of Gastric Inhibitory Polypeptide antiserum on glucose-induced insulin secretion in rats. Endocrinol 111: 1601-1606

43. Ebert R, Unger H, Creutzfeldt W (1983) Preservation of incretin activity after removal of gastric inhibitory polypeptide (GIP) from rat gut extracts by immunoadsorption. Diabetologia 24: 449-454

Received: 6 May 1985

and in revised form: 28 October 1985

Professor W. Creutzfeldt

Division of Gastroenterology and Metabolism

Department of Medicine

Robert-Koch-Str. 40

D-3400 Göttingen

FRG 